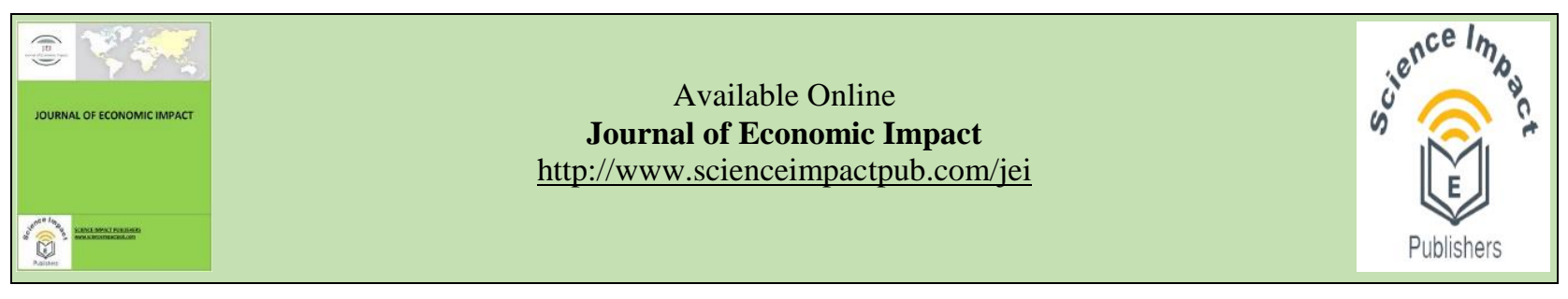

\title{
BIO-ECONOMIC IMPLICATIONS OF FEEDING FERMENTED GROUND MATURE Prosopis juliflora PODS TO GROWER RABBITS
}

\author{
Jane A Odero-Waitituh ${ }^{\mathrm{a}, *}$, Anthony M King'ori a, Mary K Ambula ${ }^{\text {a }}$ \\ ${ }^{a}$ Department of Animal Sciences, Egerton University, P. O. Box 536-20115 Njoro, Kenya
}

\section{HIGHLIGHTS}

- Prosopis juliflora plant is readily available in arid and semi-arid lands (ASALs) of Kenya to produce mature pods throughout the year.

- Its inclusion in livestock diets compromises performance due to anti-nutrients which can be reduced using fermentation.

- The study investigated the effect of inclusion of graded levels of fermented ground mature Prosopis juliflora pods (FGMPP) replacing maize in the diets of growing rabbits on growth and economic benefit.

- The study shows that 30\% FGMPP inclusion resulted in a superior average daily gain and economic benefit.

- Findings of the study will ensure sustainability in rabbit production, improvement of farmer livelihoods, and improvement of food and nutritional security to the Kenyan human population.

\begin{abstract}
Prosopis juliflora plant is readily available in arid and semi-arid lands (ASALs) of Kenya, producing mature pods throughout the year. However, its inclusion in livestock diets compromises performance due to anti-nutrients which can be reduced using fermentation. At Tatton Agriculture Park, Egerton University, a study was done to investigate the effect of inclusion of graded levels of fermented ground mature Prosopis juliflora pods (FGMPP) replacing maize in the diets of growing rabbits on growth and economic benefit. Sixty (60), 42-day old rabbits weighing $0.5 \pm 0.04 \mathrm{~kg}$ (mean $\pm \mathrm{SD}$ ) were housed in cages measuring $(75 * 55 * 40) \mathrm{cm}$; three rabbits of the same sex per cage. In a randomized complete block design (RCBD) 5 diets; control (formulated standard grower diet), $15 \%$ unfermented ground mature pods of Prosopis juliflora (UGMPP), 30\% UGMPP, 15\% FGMPP and 30\% FGMPP replacing maize in formulated standard grower diets were offered in four replicates per treatment (six males and six females). Analysis of data was done using the general linear model (GLM) of Statistical Analysis Systems (SAS). Tukey's range procedure at $(p<0.05)$ significance was used to separate means. The results show that $30 \%$ FGMPP inclusion resulted in a superior $(p<0.05)$ average daily gain (ADG) and economic benefit $(p<0.05)$. The study concluded that replacing $30 \%$ maize in diets of grower rabbits with FGMPP will make economic sense. This will ensure sustainability in rabbit production, improvement of farmer livelihoods, and improvement of food and nutritional security to the Kenyan human population.
\end{abstract}

Keywords: Economic benefit; fermentation; growth; non-conventional feed resource.

Received: March 22, 2020; Accepted: June 09, 2020; Published: June 15, 2020.

* Correspondence: Ministry of Livestock Development, PO Box 1791-20100, Nakuru, Kenya.

Email: atiwaitts@gmail.com

\section{Introduction}

In the 2019 census, Kenyan human population stood at 47.6 million (KNBS, 2019) up from 37.7 million in 2009 (KNBS, 2009), recording an intercensal 2.2\% growth (KNBS, 2019). According to Djurfeldt and Wambugu (2011) maize is Africa's largest contemporary staple crop and food. About $87 \%$ of Kenyans consume maize, every person at 400 grams per day (Shephard, 2008). In 2013, Kenya produced 3 million tonnes of maize which was far below the estimated national consumption of 4 million tonnes (Chisholm, 2013). The effect of global warming has worsened the situation with unpredictable weather patterns experienced interfering with crop and maize production (Ochieng et al., 2016). In Kenya, maize is used in formulating commercial feeds for non-ruminants as rabbits to provide energy. Most agro-industrial by-products like corn bran, rice bran, palm kernel meal, brewers dried grains exhibit low energy values ranging from $9.76 \mathrm{MJ} / \mathrm{Kg}$ sample to $11.96 \mathrm{MJ} / \mathrm{Kg}$ sample. These values are lower than ME value for maize at $12.86 \mathrm{MJ} / \mathrm{Kg}$ sample. This has necessitated the use of maize to boost the energy density of the feeds (Iyayi and Aderolu, 2004). However, the production of maize is majorly rain-fed (Lewis et al., 1998), with a reduction in production in recent years due to climate change (Mati, 2000; Ochieng et al., 2016). This has led to a fluctuation in availability and price of commercial feeds during periods of scarcity, leading to low rabbit productivity. Also, it has created the need for use of livestock feed ingredient that is available throughout the year, with less competition with man and 
with a comparable ME value to maize. Mature pods from Prosopis juliflora plant is such a feed ingredient resource in Kenya (King'ori et al., 2011).

Prosopis juliflora is considered an invasive multipurpose dry land tree or shrub that is readily available in the Kenyan arid and semi-arid lands (ASALs). The ASALs of Kenya comprise $75 \%$ of the landmass with Prosopis growing and producing throughout the year (King'ori et al., 2011). OderoWaitituh et al. (2016) reported mature Prosopis juliflora pods with $12.8 \mathrm{MJ} / \mathrm{Kg}$ metabolizable energy (ME) value which was superior to most agro-industrial by-products ME values but was comparable to maize. Reports by Wanjohi et al. (2017) state that 20\% inclusion of mature Prosopis pods in indigenous chicken diets supported the growth and organoleptic tests reported comparable sensory attributes when compared with the reference diet. However, a study done by OderoWaitituh et al. (2016) was of a contrary opinion. when investigating the possibility of using mature ground pods of Prosopis juliflora, in broilers; there were reports of reduction in feed intake and growth as mature Prosopis pods inclusion was increased in broiler diets, and suggestions made that, this could have been due to high crude fibre- $17 \%$ and tannins- $8 \%$. Fermentation has been reported to enhance the nutritional value of feed ingredients and reduce anti-nutrients (Iyayi and Aderolu, 2004; Yusuf et al., 2008). Studies by Sarasvati et al. (2014) and Aremu et al. (2015) to investigate methods of reduction of the anti-nutrients and enhancement of nutritional value, reported that fermentation significantly reduced the anti-nutrients (phytic acid, $\mathrm{CF}$, tannins) and improved essential amino acid and protein content in Prosopis pods with animals exhibiting positive performance indices (Chovatiya et al., 2018).

Bio-economic value analysis is important in ensuring that animal production makes economic sense when the feed being investigated is used to replace the conventional feed. Several researchers have reported increased feed costs per unit muscle deposition when livestock feed ingredients were treated. For instance Maidala et al. (2011) and Akintunde et al. (2015) when weaner rabbits were offered diets containing differently treated soybean (Glycine max $(L)$ Merrill) product and Japanese Quails fed processed pigeon pea (Cajanus cajan) seeds respectively. However, Yusuf et al. (2008) and Maidala, (2015) were of contrary opinion when broiler chickens were offered Prosopis africana seeds that were decorticated then fermented and processed African locust bean respectively; reports were made that treated feeds had a superior cost-benefit. The bioeconomic implication is an important parameter to be considered to ensure the product is cheaply produced when fermented Prosopis pods are used in grower rabbit diets. There is scanty information available on bioeconomic implications of feeding grower rabbits fermented ground mature Prosopis pods. This study sort to evaluate the bio-economic implications of feeding grower rabbits graded levels of fermented ground mature Prosopis juliflora pods.

\section{Methodology}

\section{Prosopis harvesting, drying, storage and grinding}

Prosopis pods were gotten from Baringo County, Marigat Sub County, about $130 \mathrm{~km}$ from the study site. Marigat is located in a semi-arid area, 1067 meters above sea level; lies within longitude $35^{\circ} 30^{\prime}$ East and $36^{\circ} 30^{\prime}$ West; latitude $0^{\circ} 10^{\prime}$ South and $1^{\circ} 40^{\prime}$ North. Annual precipitation occurs in two seasons: March to August and November to December averaging $512 \mathrm{~mm}$ with a mean temperature of about $32.8^{\circ} \mathrm{C} \pm 1.6^{\circ} \mathrm{C}$ (Ezenwa et al. 2018). Dry ripened brownish-yellow mature pods collected from the ground after tree shaking. The pods were then selected to ensure that only whole pods were picked. This was to prevent infection with aflatoxin (Choge et al., 2007). They were put in airtight bags and transported to Egerton University for grinding and fermentation. Pods were dried in the sun to a constant weight. First grinding of the pods was done without passing through a sieve. The procedure by Choge et al. (2006) was used in the second grinding the flour passed through a $5 \mathrm{~mm}$ sieve. The ground pods were kept in airtight containers to prevent regaining moisture.

\section{Study site}

Amino acid analysis was conducted at the National Centre for International Research on Animal Gut Nutrition, Nanjing Agricultural University, 210095, Peoples Republic of China, China in November 2018. Nanjing is located at latitude $32^{\circ} 03^{\prime} 42.01^{\prime \prime} \mathrm{N}$ and longitude $118^{\circ} 46^{\prime} 40.01^{\prime \prime} \mathrm{E}$ with an average altitude of 150 feet above sea level. There are about 115 rainy days in a year, and the average annual rainfall is $1,100 \mathrm{~mm}$. The annual mean temperature is $3^{\circ} \mathrm{C}$ in January and $280 \mathrm{C}$ in July.

Proximate analysis and feeding trial were conducted at Tatton Agricultural Park (TAP) rabbit unit, Egerton University; at latitude $0^{\circ} 23^{\prime} \mathrm{S}$ and longitude $35^{\circ}$ $57^{\prime} \mathrm{E}$; an altitude of $2,238 \mathrm{~m}$ above sea level with a mean daily temperature of $21 \mathrm{oC}$. The average annual rainfall is $900-1,020 \mathrm{~mm}$ and bimodal (March to May and June to September) (Egerton University Meteorological Station, 2019).

\section{Fermentation of Prosopis juliflora pods}

The ground pods were subjected to solid-state fermentation in airtight containers where $5 \mathrm{~kg}$ of ground Prosopis juliflora floor was mixed with distilled water $(1: 1 \mathrm{~W} / \mathrm{V})$ according to a modified procedure by Sarasvati et al. (2014). The substrate was then left to undergo anaerobic fermentation spontaneously for 72 hours. The fermented substrate was then solar dried between 9.00 and 15.00 hours daily until a constant weight was achieved. The solar drier was fabricated locally at Agricultural Technology Development Centre (ATDC) Nakuru, Kenya. 


\section{Proximate analysis}

Proximate composition of dried samples of FGMPP, UGMPP, and feed ingredients was analyzed using the standard procedures of the Association of Official Analytical Chemists AOAC International, (1990). DM was determined according to the AOAC International, (1990) standard procedures. Nitrogen was determined using Kjedhal's method. Nitrogen values gotten were multiplied by 6.25 to get the CP content. Ether Extract content was gotten following the Soxhlet extraction procedure. $100 \%$ minus the sum total of, $\%$ crude protein (CP) \% crude ether extract (EE), \% ash, and $\%$ crude fibre $(\mathrm{CF})$ gave Nitrogen free extract (NFE) values.

\section{Amino Acid (AA) analysis of the feed ingredients}

Hydrolysis of samples in the gas phase was done using $6 \mathrm{M} \mathrm{HCl}$ at $115{ }^{\circ} \mathrm{C}$ for $24 \mathrm{hr}$. Amino acids were then liberated and converted to phenylthiocarbamyl derivatives which were then analyzed by high-pressure liquid chromatography (HPLC) on a PicoTag $3.9 \times 150$ mm column (Marangoni and Alli, 1988).

\section{Experimental animals and management}

Sixty, 60 (42 days old) New Zealand White grower rabbits (30 males and 30 females) were used. They were housed in cages $(75 * 55 * 40) \mathrm{cm}$. The rabbits were reared for 3 days on formulated standard grower diet (Deblas and Mateo, 2010) for adaptation before the commencement of the experiment. During this period, disease control measures were done. The rabbits were dewormed with ascarex ${ }^{\circledR}$ and dusted with Sevin ${ }^{\circledR}$ dududust for control of internal and external parasites respectively. Before introducing the rabbits to the experimental cages, watering and feeding troughs were thoroughly cleaned, disinfected with kupacide ${ }^{\circledR}$ and dusted with Sevin ${ }^{\circledR}$ against external parasites.

Management of Tatton Agriculture Park authorized our use of the rabbit unit. The unit observes measures for maintenance of biosecurity and prevention of disease transmission. Authority to use live animals was obtained from the Institute of Primate Research on compliance with the international code of animal ethics in research. Authority to conduct the research was obtained from the National Commission for Science Technology and Innovation in compliance with international code for permission and clearance to conduct research. Regular observation of the rabbits was done by staff from the Faculty of Veterinary Medicine, Egerton University. Any ill health was therefore detected on time and necessary measures taken. Ad-libitum provision of feed and water was done using manual feeders and drinkers throughout the experimental period.

\section{Experimental design and dietary formulations}

Sixty (60) 42-day old New Zealand White grower rabbits with similar body weights were used. They were randomly allocated to twenty experimental units with three rabbits each. Five (5) dietary treatments of; Control/formulated standard grower diet; 15\% FGMPP; $30 \%$ FGMPP; $15 \%$ UGMPP; and 30\% UGMPP inclusions were randomly allocated to the experimental units such that there were six female grower rabbits and six male grower rabbits for each treatment (12 rabbits/ treatment) in a randomized complete block design (RCBD).

Table 1: Composition of experimental diets

\begin{tabular}{|c|c|c|c|c|c|}
\hline & & & Treatments & & \\
\hline Ingredient & 30\%UGMPP & 15\%UGMPP & 30\% FGMPP & 15\%FGMPP & Control \\
\hline Maize & - & 15 & - & 15 & 30 \\
\hline Wheat bran & 22.3 & 15 & 21.5 & 15.2 & 20 \\
\hline Maize germ & 13.5 & 20.5 & 14 & 20 & 15 \\
\hline Rice husks & 13 & 14 & 15 & 15 & 15.4 \\
\hline UGMPP & 30 & 15 & - & - & - \\
\hline FGMPP & - & - & 30 & 15 & - \\
\hline SFC & 18.2 & 17.5 & 16.5 & 16.8 & 16.6 \\
\hline Bone meal & 2.0 & 2.0 & 2.0 & 2.0 & 2.0 \\
\hline Iodized salt & 0.5 & 0.5 & 0.5 & 0.5 & 0.5 \\
\hline Vit premix $*$ & 0.5 & 0.5 & 0.5 & 0.5 & 0.5 \\
\hline Totals & 100 & 100 & 100 & 100 & 100 \\
\hline \multicolumn{6}{|c|}{ Calculated nutrient composition } \\
\hline $\mathrm{CP}(\%)$ & 16.2 & 15.9 & 16.2 & 15.9 & 15.8 \\
\hline $\mathrm{ME}(\mathrm{MJ} / \mathrm{kg})$ & 9.78 & 9.82 & 9.78 & 9.82 & 9.84 \\
\hline $\mathrm{CF}(\%)$ & 15.9 & 15.8 & 15.9 & 15.8 & 15.5 \\
\hline
\end{tabular}


Each rabbit was ear numbered and parameter taken on the same rabbit throughout the experimental period. Proximate analysis was done on the feed ingredients to be used before experimental dietary formulation. The dietary treatments were formulated to a nutrient content of $9.8 \mathrm{MJ} / \mathrm{kg}$ feed ME and 16\% CP (Deblas and Mateos, 2010).

\section{Data collection, cost benefit analysis and statistical analysis}

The difference in feed offered and feed refusal for each experimental unit by the end of each day was considered as the daily feed intake (FI). Total feed intake was taken for the entire experimental period. The weight gain was calculated as the difference in weight at the beginning and end of the experiment. The rabbits were fasted overnight before slaughter. Weights for live and dressed carcass were recorded. Feed ingredients costs were estimated by identifying the ingredients that varied across the treatments, quantifying their level input in each treatment and estimating their unit price. The ingredients considered were FGMPP, UGMPP, rice husks, wheat bran, maize germ, maize, sunflower cake, bone meal, iodized salt and vitamin premix. The output item was the dressed carcass weight of the grower rabbit meat with its estimated price.

The following expression was used in estimating the benefits and costs.

$$
\mathrm{BC}=\frac{\left(\mathrm{KP} \times \mathrm{P}_{1}\right)}{\sum\left(\% \mathrm{I}_{(1,2,3 \ldots \mathrm{r})} \times \mathrm{P}_{0(1,2,3 \ldots \mathrm{r})}\right) \mathrm{F}} \quad \text { (Equation 1) }
$$

Where;

$\mathrm{BC}$ is benefit-cost.

$\mathrm{KP}$ is no. of Kilograms of final product.

$\mathrm{P}_{1}$ is price of final product.

$\mathrm{I}$ is ingredient.

$\mathrm{P}_{0}$ is price of corresponding ingredient.

$\%$ is percentage ingredient in $1 \mathrm{~kg}$ diet

$\mathrm{F}$ is no. of kilograms feed fed

Data from price of feed ingredients and price of meat were fitted into the cost benefit analysis equation (Equation 1). This was done in excel spreadsheets 2010 and the cost benefit of feeding the various diets computed. The treatment with highest cost benefit value was considered cost effective and therefore the cheapest diet per unit gain. SPSS Statistics 25.0.0 software was used to analyze the data normality and homogeneity of variance. The data were then subjected to analysis of variance using the general linear model (GLM) of Statistical Analysis Systems (SAS, 9.1.3) computer package. Mean separation at $(\mathrm{p}<0.05)$ probability values were done using the Tukey's range test and considered significant.

\section{Results and Discussion}

Proximate compositions of the ingredients used in the formulation of experimental diets are presented in (Table 2). Amino acid (AA) profile of Maize, UGMPP and FGMPP are presented in table (Table 3 ). There was nutritional enrichment on fermentation (Tables 2 and 3) especially the limiting amino acids in rabbit nutrition (Table 3).

Table 2: Proximate fractions \%DM and energy of feed ingredients used in the experimental diets

\begin{tabular}{lccccccc}
\hline Ingredient & \%DM & \% CF & \% CP & \% EE & \%Ash & ME & \% CHO \\
\hline MG & 90.8 & 8.7 & 9.76 & 12.2 & 2.7 & 14.9 & 62.8 \\
Maize & 88.6 & 2.8 & 8.21 & 7.12 & 0.7 & 14.3 & 71.6 \\
RH & 93.7 & 29.2 & 7 & 5.51 & 17.5 & 7.91 & 33.6 \\
WB & 89.2 & 11.6 & 16.7 & 7.81 & 4.7 & 12.3 & 48 \\
SFC & 94.5 & 29.4 & 22.8 & 15.4 & 5.8 & 12 & 22.3 \\
FGMPP & 84.2 & 26.6 & 14 & 1.77 & 4.89 & 8.29 & 37.6 \\
UGMPP & 88.3 & 32.9 & 10.2 & 2.62 & 3.81 & 8.03 & 37.7
\end{tabular}

DM = Dry matter $;$ DM calculated on air dry basis; SFC = Sunflower cake; $M G=$ Maize germ; RH = Rice husks; WB = Wheat bran; UGMPP = Unfermented ground mature Prosopis juliflora pods; FGMPP = Fermented ground Prosopis juliflora pods; ME $=$ Metabolizable Energy mega joules $/$ Kg sample $; C F=$ Crude Fibre; $C P=$ Crude protein, $C H 2 O=$ Carbohydrates; $E E=E t h e r$ extract. 
Table 3: Essential amino acid profile of maize, UGMPP and FGMPP in mg/g DM

\begin{tabular}{|c|c|c|c|}
\hline Parameter & Maize & UGMPP & FGMPP \\
\hline \multicolumn{4}{|l|}{ Essential AA } \\
\hline Arginine* & 3.94 & 4.95 & 6.94 \\
\hline Lysine* & 2.98 & 3.65 & 4.84 \\
\hline Methionine* & 4.56 & 4.57 & 4.1 \\
\hline Leucine & 2.83 & 0.36 & 0.3 \\
\hline Phenylanine & 2.11 & 1.38 & 1.89 \\
\hline Tyrosine & 6.87 & 5.84 & 7.31 \\
\hline Threonine & 3.38 & 0.01 & 0.01 \\
\hline Tryptophan & 4.27 & 0.05 & 4.42 \\
\hline Valine & 4.27 & 4.44 & 5.12 \\
\hline Histidine & 1.66 & 1.2 & 1.57 \\
\hline TAAs & 57.6 & 47.6 & 54 \\
\hline TEAAs & 30 & 20.7 & 29.2 \\
\hline
\end{tabular}

Table 4: Economics of production of grower rabbits fed FGMPP and UGMPP

\begin{tabular}{|c|c|c|c|c|c|c|c|}
\hline & $\begin{array}{c}30 \% \\
\text { UGMPP }\end{array}$ & $\begin{array}{c}15 \% \\
\text { UGMPP }\end{array}$ & $\begin{array}{c}30 \% \\
\text { FGMPP }\end{array}$ & $\begin{array}{c}15 \% \\
\text { FGMPP }\end{array}$ & Control & SEM & p-value \\
\hline Initial wt (Kg) & $0.45^{\mathrm{a}}$ & $0.48^{a}$ & $0.49^{a}$ & $0.5^{\mathrm{a}}$ & $0.53^{\mathrm{a}}$ & 0.04 & 0.13 \\
\hline Final wt (Kg) & $1.34^{\mathrm{a}}$ & $1.25^{\mathrm{a}}$ & $1.36^{\mathrm{a}}$ & $1.23^{\mathrm{a}}$ & $1.29^{\mathrm{a}}$ & 0.07 & 0.14 \\
\hline $\mathrm{Wt}$ gain $(\mathrm{Kg})$ & $0.89^{c}$ & $0.77^{b}$ & $0.87^{\mathrm{c}}$ & $0.73^{\mathrm{a}}$ & $0.76^{b}$ & 0.008 & 0.0001 \\
\hline Total FI (Kg) & $3.41^{\mathrm{e}}$ & $3.23^{\mathrm{d}}$ & $3.02^{\mathrm{b}}$ & $3.15^{\mathrm{c}}$ & $2.95^{\mathrm{a}}$ & 0.014 & 0.0001 \\
\hline DC wt(Kg) & $0.65^{\mathrm{bc}}$ & $0.58^{b}$ & $0.67^{c}$ & $0.60^{\mathrm{bc}}$ & $0.55^{\mathrm{ab}}$ & 0.013 & 0.0004 \\
\hline Mortality \% & 16.7 & 25 & 8.33 & 16.7 & 25 & - & - \\
\hline $\mathrm{BC}$ value & $3.56^{\mathrm{d}}$ & $2.78^{\mathrm{a}}$ & $3.76^{\mathrm{e}}$ & $2.92^{\mathrm{b}}$ & $3.03^{\mathrm{c}}$ & 0.01 & 0.0001 \\
\hline
\end{tabular}

\section{SEM $=$ Standard error of means}

$a, b, c=$ Means in the same column with different superscripts are significantly different $(P<0.05) ; \operatorname{Trt} 1=30 \%$ UGMPP; Trt $2=15 \%$

UGMPP; Trt $3=30 \%$ FGMPP; Trt $4=15 \%$ FGMPP; Trt $5=$ Control; FGMPP = Fermented ground mature Prosopis pods;

$U G M P P=$ Unfermented mature Prosopis pods; $B C=$ Cost benefit; $F I=$ Feed intake; $D C=$ Dressed carcass; Wt $=$ weight .

The feed with the least cost per unit weight gain and highest $B C$ is desired.

* The calculations were done based on the prevailing price of ingredients at the time of study.

Proximate composition of FGMPP was higher in $\mathrm{CP}$ and amino acids with reduced CF content (Table 2). Similar results were reported by Chovatiya et al. (2018) when studying the effect of feeding Prosopis juliflora pods fermented and treated with probiotics to fingerlings. The cost-benefit (BC) values increased as the inclusion of UGMPP and FGMPP increased (Table 4) with the highest $\mathrm{BC}$ experienced in meat from rabbits offered treatments with $30 \%$ FGMPP. This is in accordance with reports by Yusuf et al. (2008) when broiler chickens were fed fermented decorticated Prosopis africana seed meal; where it was reported that there was economic benefit of feeding fermented decorticated Prosopis africana seed meal as compared to all other diets. However, it is contrary to reports by Maidala et al. (2011) and Akintunde et al. (2015) that treatment of feed ingredient offered to rabbits increased the cost of rearing. Fermenting ground mature Prosopis pods increased the cost-benefit values and therefore lower costs per unit gain in the current study. Weight gain and dressed carcass weights for the rabbits offered 30\% UGMPP and 30\% FGMPP are similar
(Table 4). However, the rabbits offered 30\% UGMPP exhibited a higher total feed intake as compared to the rabbits offered $30 \%$ FGMPP. It may seem that the benefit of cost of fermentation in the current study could have been from the efficiency of feed utilization, and improved gut health, resulting in improved deposition of muscles and therefore weight gain (Montiel et al., 2013; Chovatiya et al., 2018). This is in accordance with studies conducted by Maidala (2015) on the effects of different treatment methods of African locust bean on broiler meat production costs. Fermentation in the current study was spontaneous, which could have resulted in lower costs as compared to when microbial fermentation could have been used. Also, muscle tissue deposition depends on the efficiency of feed utilization which seems to have been superior in the rabbits offered $30 \%$ FGMPP.

\section{Conclusions}

The results show that rabbit's offered $30 \%$ FGMPP inclusion exhibited the highest $\mathrm{BC}$ values and therefore the best cost-benefit compared to all other treatments. It 
is therefore concluded that $30 \%$ FGMPP inclusion in grower rabbit diets will ensure improved rabbit performance due to availability of rabbit feeds in quantity, quality and price. This will reduce the cost of producing rabbits; improve the livelihoods of farmers who keep rabbits and ensure food and nutrition security to the human population.

\section{Approval of the Research}

National Commission for Science Technology and Innovation (NACOSTI), Kenya, gave permission for the research to be conducted; clearance permit No: NACOSTI/P/19/37739/31032. Institute of Primate Research of Kenya gave the ethical approval for use of live animals; Reference number ISERC/14/2018.

\section{Acknowledgements}

We acknowledge and appreciate the World Bank through the Center of Excellence in Sustainable Agriculture and Agribusiness Management (CESAAM), (Egerton University Kenya) for funding the Research and Tracy Nyokabi Waitituh for assisting in the development of Cost Benefit analysis equation.

\section{Authors' Contribution}

Author Jane A Odero-Waitituh conceptualized the study, did the literature searches, collected and analyzed the data, interpreted the data, drafted the manuscript and did the conclusions; Authors Anthony M King'ori and Mary K Ambula performed literature searches, interpretations and revisions. The final manuscript was read and approved by all authors.

\section{Declaration of any conflict of interest by the authors}

There is no any conflict of interests.

\section{References}

Akintunde, A.R., Omage, J.J., Bawa, G.S., 2015. Effect of differently processed pigeon pea (Cajanus cajan) seeds on the performance of Japanese quails. Proceedings of the 40th Annual Conference of the Nigerian society for Animal Production. 15-19th March, 2015, NAPRI/ABU, Zaria. Pp 675-67

Aremu, M.O., Awala, E.Y., Opaluwa, O.D., Odoh, R., Bamidele, T.O., 2015. Effect of processing on nutritional composition of African locust bean (Parkia biglobosa) and mesquite bean (Prosopis africana) seeds. Communications in Applied Sciences, 3(1), 22-41.

Association of Official Analytical Chemists (AOAC) 1990. Official methods of analysis: $\left(15^{\text {th }}\right.$ Ed.) USA, Washington, DC.

Chisholm, N., 2013. Kenya food prices and how people are eating. Oxfam case study. Retrieved from https://oxfamilibrary.openrepository.com/bitstream/handle /10546/325107/cs-food-prices-and-how-people-areeating-kenya-2013-260814en.pdf? sequence $=5 \&$ is Allowed $=y$

Choge, S.K., Harvey, M., Chesang, S., Pasiecznik, N.M., 2006. Cooking with prosopis flour recipes tried and tested in Baringo district, Kenya. Nairobi and Coventry, KEFRI and HDRA.
Choge, S.K., Pasiecnik, N.M., Harvey, M., Wright, J., Awan, S.J., Harris, P.J.C., 2007. Prosopis pods as human food, with special reference to Kenya. Retrieved on 22/03/2020 https://www.ajol.info/index.php/wsa/article/view/49162

Chovatiya, S., Bhatt, S., Shah, A., Dube, P., 2018. An investigation on the use of Prosopis juliflora pods as a carbohydrate source supplemented with probiotics in the diet of Labeo rohita fingerlings. Iranian Journal of Fisheries Sciences, 17(2), 327-345.

Deblas, C., Mateos, G.G., 2010. Feed formulation. p. 222. In: Deblas, C., Wiseman, J. (eds), Nutrition of the rabbits CAB International. United Kingdom.

Djurfeldt, A.A., Wambugu, S.K., 2011. In-kind transfers of maize, commercialization and household consumption in Kenya. Journal of Eastern African Studies, 5(3), 447-464.

Egerton University Meteorological Station., 2019. Climatic data. Egerton University, Njoro Campus, Kenya.

Ezenwa, L.I., Omondi, P., Ubuoh, E., Nnamerenwa, G.C., 2018. Effects of climatic variability on livelihood choices among rural populace in Baringo County, Kenya and Jigawa State, Nigeria. Journal of Research in Forestry, Wildlife and Environment, 10(4), 55-70.

Iyayi, E. A., Aderolu, Z. A., 2004. Enhancement of the feeding value of some agro-industrial by-products for laying hens after their solid state fermentation with Trichoderma viride. African Journal of Biotechnology, 3(3), 182-185.

King'ori, A.M., Odero-Waitituh, J.A., Guliye, A.Y., 2011. Mathenge (Prosopis juliflora): An underutilized Livestock Feed Resource in Kenya. Research Journal of Animal Sciences, 5(4-6), 43-51.

KNBS., 2009. Population and housing census results: Kenya census 2009. Retrieved on 2/03/2020 from http://statistics.knbs.or.ke/nada/index.php/catalog/55/dow nload $/ 375$

KNBS., 2019. Population by county and sub-county: Kenya Population and Housing Census Volume I: Retrieved on 22/03/2020 from https://www.knbs.or.ke/?p=5621

Lewis, J.E., Rowland, J., Nadeau, A., 1998. Estimating maize production in Kenya using NDVI: Some statistical considerations. International Journal of Remote Sensing, 19(13), 2609-2617.

Maidala, A., 2015. Cost benefit analysis of broiler chickens fed African locust bean (Parkia biglobosa) seeds as affected by different processing. International Journal of Agriculture and Earth Science, 1(8), 20-24.

Maidala, A., Doma, U.D., Ajighjigh, D.T., 2011. Growth performance of weaner rabbits fed diets containing different processed soybean (Glycine $\max (L)$ Merrill) product. Proceedings of 36th Annual Conference of the Nigerian Society of Animal production 13-16th March 2011 University Abuja. Vol. 36, pp. 13-16

Marangoni, A., Alli, I., 1988. Composition and properties of seeds and pods of the tree legume Prosopis juliflora (DC). Journal of the Science of Food and Agriculture, 44(2), 99-110.

Mati, B.M., 2000. The influence of climate change on maize production in the semi-humid-semi-arid areas of Kenya. Journal of Arid Environments, 46(4), 333-344.

Montiel, R.S., Acosta, I.T., Delgado, E.V., Juárez-Silva, M.E., Azaola, A., Romo, F.P.G., 2013. Inulin as a growth promoter in diets for rabbits. Revista Brasileira de Zootecnia, 42(12), 885-891.

Ochieng, J., Kirimi, L., Mathenge, M., 2016. Effects of climate variability and change on agricultural production: The case of small scale farmers in Kenya. NJAS-Wageningen Journal of Life Sciences, 77, 71-78. 
Odero-Waitituh, J.A., King'ori, A.M., Guliye, A.Y., 2016. Effect of replacing maize with milled mature pods of Prosopis juliflora on performance of finishing broiler chicken. Livestock Research for Rural Development. Volume 28, Article \#22. Retrieved March 13, 2020, from http://www.lrrd.org/lrrd28/2/oder28022.htm

Sarasvati, S., Bhatt, S., Shah, A., 2014. Effects of fermentation on nutritional quality of Prosopis juliflora pods as alternative fish feed. Research Journal of Animal, Veterinary and Fishery Sciences, 2(12), 1-7.

Shephard, G.S., 2008. Risk assessment of aflatoxins in food in Africa. Food Additives and Contaminants, 25(10), 12461256.
Wanjohi, D.M., King' ori, A.M., Wachira, A.M., Guliye, A.Y., Ngoda, P.N., 2017. Sensory attributes and quality of meat in improved indigenous chicken fed on Prosopis juliflora pods in Kenya. African Journal of Food Science and Technology, 8(8), 132-137.

Yusuf, N.D., Ogah, D.M., Hassan, D.I., Musa, M.M., Doma, U.D., 2008. Effect of decorticated fermented Prosopis seed meal (Prosopis africana) on growth performance of broiler chicken. International Journal of Poultry Science, 7(11), 1054-1057. 